\title{
A Servant. A Hanging. A Paper House
}

Pity silk in the elbows,

I rose like a flannel

throat in a fire

of fog. Once an apple

biter-now gumming

ghost leavings. Wisps

of chambermaid keys blinking

through my lips. Entreat

the door knob-Silent,

but overused in the upstairs

sky. Fingerprints rushing

the wood. Jack hammer

wrists splintered \& paralyzed.

Crack-\& the tin pops

open-flooding out scarlet

seminary ribbons. Pausing

to notate a pregnant

wing. In the center

of a glittering scream

hangs an egg. Icy

\& blue-left and that

is to say, I love you

and could you please

return to me my tongue. 